\title{
CTNNB1 Gene Mutation Negative
}

National Cancer Institute

\section{Source}

National Cancer Institute. CTNNB1 Gene Mutation Negative. NCI Thesaurus. Code C160351.

A genetic finding indicating that CTNNB1 gene mutations have not been detected in a sample. 